Schelhammer Zsófia

\title{
Gyöngyösi és Zrínyi megjelenése egy 17. századi énekeskönyvben*
}

Petrovay Miklós énekeskönyve ${ }^{1}$ a régi magyar irodalom elképesztően gazdag repertoárját vonultatja fel, gyakorlatilag nincs „müfaj”, amely ne képviseltetné magát benne - könnyedén megférnek egymás mellett a 16 . századi históriás énekek, a „kortárs” vagy „közel kortárs” irodalmi szövegek, a dráma, a dal, a népkönyvrészletek, valamint a Csízió is. E dolgozat azonban csak a kortárs szövegekre fókuszál, pontosabban Gyöngyösi István és Zrínyi Miklós énekeskönyvbeli megjelenésére. Mindkettőjüket megidézi egy-egy szöveg, azonban szerintem nemcsak Zrínyit, hanem - a szakirodalom álláspontjával ellentétben - Gyöngyösit is csupán közvetve.

Az első ének, amelyről szó lesz, az énekeskönyvben Quaerela puellae nupturientis címen ${ }^{2}$ szerepel a 100v-101v és a 130v oldalakon. Ferenczi Zoltán a kéziratot ismertető tanulmányában ${ }^{3}$ közli a Szerelem anyjának... incipitü vers szövegét, azonban csupán annyit füz hozzá, hogy „Terjed a 100b-101 levélre. A 12 versszak utolsó 2 során kezdve az ének a 130b lapra van beírva. Utána ez áll: "Leányokrul való szép versek férhezmenetekrül való.«"

A magyar irodalom története második kötetében azt a megállapítást olvashatjuk, hogy ezek a strófák Gyöngyösitől erednek. ${ }^{5}$ Ott azonban nem azonosították a forrásszöveget, amely az Igaz barátságnak és szíves szeretetnek tüköre (népszerübb nevén a Florentina). Electra monológját olvashatjuk itt, kissé átköltve (3. felvonás 5. jelenet). A szöveg azonban nemcsak azért problémás, mert más verzióban szerepel a lapokon, hanem azért is, mert több részletben található meg a kéziratban. Ahogy Ferenczi is írta, a nagyobb része a $100 \mathrm{v}-101 \mathrm{v}$ oldalakon olvasható, a 101v oldal alján valóban látjuk is az őrszót, ez azonban a 130v oldalra mutat, ahol az ének minden megszakítás nélkül, valóban úgy folytatódik, ahogy

\footnotetext{
* A szerző az Emberi Erőforrások Minisztériumának Szegedi Kis István Kutatói Ösztöndíjasa.

1 Stoll Béla, A magyar kéziratos énekeskönyvek és versgyüjtemények bibliográfiája (15651840), Bp., Balassi, 2002², Nr. 93.

2 Férjhez menni vágyó lány panasza.

3 Ferenczi Zoltán, Petrovay Miklós énekeskönyve = Irodalomtörténeti Közlemények, 26(1916), 201-219.

4 Ferenczi 1916, i. m. 206.

5 A magyar irodalom története 1600-tól 1772-ig, szerk. Klaniczay Tibor, Bp., Akadémiai, 1964,315 .
} 
azt a 102r oldalon várnánk. Ez az anomália eredhet onnan is, hogy a kézirat lapjai összekeveredtek az idők folyamán, elképzelhető azonban az is, hogy az utolsó években jegyezte be Petrovay ezt a szöveget a füzetébe. Ez utóbbit látszik megerősíteni a tény, hogy recto oldalon kellene folytatódnia a szövegnek, mégis a 130v-n találjuk - ilyen formán pedig semmiképp nem tudnánk egymás mellé tenni őket. Ebben az esetben azonban legalábbis egy szemöldökráncolást megér a tény, hogy Petrovay semmi módon nem jelöli, hogy később folytatódik a szöveg. Pedig, ha az alig fennmaradó üres oldalak kényszerítették feldarabolni a verset, annak tükrében valószínüleg jelezve lenne mindez, ahogy a Zsigmond-história esetében is feljegyezte, hogy „ennek héja lehet”, ${ }^{6}$ illetve „héja vagyon” a szövegnek. ${ }^{7}$

Talán megér egy apró kitérőt, hogy ez a két kis megjegyzés rendkívül sokat elárul Petrovay másolási technikájáról. Meglehetősen nehéz őt akár a szolgai, akár az invenciózus másoló kategóriájába beskatulyázni; a Zsigmond királyról szóló história esetében például nem egyszerü eldönteni, mekkora része lehetett abban, hogy egybeolvasztva olvashatjuk a két szöveget, melyeket (szerintem tévesen) jelenleg külön énekekként kezel a szakirodalom. ${ }^{8}$ Az azonban elgondolkodtató, hogy miért ilyen eltérő módokon jelezte az összeolvasztást - hiszen az egyik esetben biztosan állítja, hogy hiány van a szövegben, míg a másikban csupán feltételezi. A két ének eltérő ritmusa és beosztása miatt az válik a legvalószínűbbé, hogy külön forrásokban szerepeltek, és Petrovay saját leleménye volt, hogy egybekapcsolja őket, mikor észlelte, hogy tökéletesen kiegészítik egymást. A szerinte bizonyos („héja vagyon”) és az általa feltételezett (,ennek héja lehet”) hiánnyal kapcsolatban a forrásai romlottságára gyanakodhatunk. Ugyanis mikor az első, hosszabb éneket megszakítja, és egészen biztos hangon közli, hogy hiányt regisztrált a históriában, valószínúleg azért teheti ezt, mert olyan nyomtatvány volt a kezében, melyből láthatóan ki volt szakadva egy-két oldal (az őrszók és a lapszámozás igazíthatták el ebben a kérdésben). A háromsoros, rövidebb szöveg esetében bizonytalan a hiány kérdésében, és ma már tudjuk, hogy csupán egy strófa maradt ki a másolásból, így a legvalószínűbb itt is az, hogy töredékes forrásból dolgozott, de ebben az esetben számára az utolsó oldalon ért véget a história, így nem lehetett biztos benne, valóban hiányzik-e valamennyi az énekből és vajon mekkora egység. Úgy látszik tehát, úgy kell kezelnünk Petrovayt, mint aki szolgaian lemásolja az előtte fekvő szöveget, viszont ha többletinformáció van a birtokában, azt is feljegyzi magának.

Ezen a ponton megéri elgondolkodni azon, vajon milyen forrás lehetett Petrovay kezében. Abból kiindulva, hogy mindkét forrását hiányosnak tekinthetjük, és hogy jelen esetben egy históriás énekről van szó, nagyon valószínünek tartom,

6 Petrovay-énekeskönyv, $13 \mathrm{r}$

7 Petrovay-énekeskönyv, 10r

8 Ebben a kérdésben azon az állásponton vagyok, hogy eredetileg is egyetlen költeményröl beszélhetünk, ld. SCHELHAMmer Zsófia, Tinódi ismeretlen verseiröl = VERSO, Irodalomtörténeti folyóirat, 2(2019), 3, 5-20. 
hogy ponyvanyomtatványokról beszélhetünk. A nyomtatási adatok alapján tudjuk ugyanis a népszerú irodalmi szövegekröl, hogy rendkívüli tömegben jelentették meg őket, különösen azután, hogy Komlós András (külföldi minta alapján hazánkban is) meghonosította a füzetes kiadványokat. ${ }^{9}$ Már csak az RMNy adataira támaszkodva is biztosak lehetünk abban, hogy előszeretettel vásárolták ezeket a vékony kis nyomtatványokat, hiszen, ha nem így lett volna, akkor nem szembesülnénk jó pár szöveg esetében azzal, hogy sürú időközönként újranyomták őket, ráadásul az ország különböző pontjain egyaránt. Szokás említeni ${ }^{10}$ azonban ellenpéldaként Valkai András históriáit, melyeket Heltai (vagy a felesége) a Cancionaléhoz kötött hozzá. Ezt általában annak alátámasztására szokták felhozni, hogy nem lehetett népszerü olvasmány, én azonban inkább úgy értékelném ezt a tényt, hogy közkedveltsége folytán olyan mennyiségben nyomtatták ki, amit már nem tudott felszívni a „piac” még e nagy népszerüség mellett sem. Jól megvilágítja a históriás énekek sikerét Heltainé esete, akinek férje halála után egyedül kellett fenntartania magát, megélhetést csiszolva a rámaradt nyomdából. Márpedig ő, helyzetét felmérve, szinte kivétel nélkül ilyen énekek ponyvanyomtatványait jelentette meg. ${ }^{11}$ Ez rendkívül beszédes adat egy olyan nyomdatulajdonos esetében, akinek az üzletpolitikájában elsősorban a mindennapi megélhetés számít, és aki számára az irodalmi ízlés vagy a szakmai megbecsültség csak másodlagos szempontok lehetnek.

Visszatérve a fötémára, elmondhatjuk tehát, hogy a Gyöngyösihez köthető szöveg kissé feldaraboltan, de látszólag a maga teljességében olvasható az énekeskönyvben. Petrovay másolási metódusánál jelenleg fontosabb azonban, hogy vajon honnan is másolhatta a szöveget. A szakirodalom gyakorlatilag tényként kezeli, hogy az Gyöngyösi Florentinájából származik, a két változat közötti kapcsolathoz pedig valóban kétség sem fér. Fennáll viszont a tyúk és a tojás problémája. Melyik szöveg létezhetett előbb? Badics Ferenc azt írja, Gyöngyösi valamikor 1672-1674 között írhatta a Florentinát. ${ }^{12}$ A 17. századból egyetlen másik kéziratban maradt fenn (a Gosztonyi-kódexben), ezen kívül csupán 18. századi forrásairól tudunk. A másik 17. századi forrásában, a téma kapcsán kevésbé emlegetett Petrovay-énekeskönyvben semmilyen utalást nem találunk Gyöngyösire. A Gosztonyi-kódex ${ }^{13}$ jó ideig elveszettnek számított, a Régi Magyar Drámai Emlékek 2. kötetében még azt olvashatjuk, hogy „a II. világháborúig a Balassagyarmati (Palóc) Múzeumban volt. A háború alatt ez a kódex eltünt, s bár a Múzeum kéziratos anyaga azóta az OSZK-ba került, a Gosztonyi-kódexnek ez ideig nem

9 Heltai Gáspár, Cancionale azaz históriás énekeskönyv Kolozsvár 1574, kiad., kísérő tan.

VARJAs Béla, Bp., Akadémiai, 1962 (Bibliotheca Hungarica Antiqua, V), 21.

10 Heltai 1962, i. m. 22.

11 Czintos Emese, Példától az olvasmányig, A (szép)história a 16. század magyar irodalmában, Bp., Reciti, 2017 (Irodalomtörténeti Füzetek, 179), 81.

12 BADICs Ferenc, Gyöngyösi István összes költeményei I, Régi magyar költök tára - XVII. századbeli magyar költők művei, Bp., MTA, 1914, 478.

13 STOLl $2002^{2}$, i. m. Nr. 89. 
sikerült nyomára akadnunk." ${ }^{14}$ Azóta - miként ezt Stoll Béla kéziratos énekeskönyv-bibliográfiájának második kiadása regisztrálja ${ }^{15}$ - szerencsére előkerült, így össze lehet vetni a két szövegváltozatot.

Badics arról is bővebben ír, hogy Gosztonyi és Gyöngyösi könnyen találkozhattak, így Gosztonyi valóban másolhatott eredeti Gyöngyösi-szövegeket. A kódexbe való bejegyzés dátuma természetesen bizonytalan, de Badics megemlíti, hogy a Florentina folytatása (töredékben maradt fenn a kéziratban) esetleg akkor veszhetett el, mikor 1679-ben a pestisjárvány miatt Gosztonyi „munkahelye”, a pozsonyi kamara Modorra, majd Kis-Martonba volt kénytelen menekülni. Ekkor tehát elméletben már szerepelhetett a kódexben a szöveg. De hogyan juthatott Petrovay birtokába? Az ő életéről alig rendelkezünk információval, viszont a kézirat összeállításának dátuma a benne szereplő szövegek alapján 1668-1677 közé tehető. Ez azonban a legszélesebb időintervallum, amiben mozoghatunk, az 1677-es bejegyzés például egy személyes jegyzet, amely más színü tintával, kapkodóbb kézírással, és az énekeskönyvből kihámozható dátumokkal összevetve rendkívül későn született, a kézirat törzsanyaga ugyanis valószínűleg 1671-72 között került lejegyzésre. De még ha megengedően gondolkodunk is, és azt mondjuk, hogy a Florentina-beli versbetét 1667 táján született, ${ }^{16}$ a legjobb esetben akkor is mindössze tíz évet számolhatunk addig, míg Petrovay (mai tudásunk szerint) felhagy a bejegyzésekkel. Mekkora esély van rá, hogy Gyöngyösi saját költeménye ennyi idő alatt utat talált volna Petrovay Miklóshoz?

A kérdés nem újkeletü, már Lengyel Dénes is felfigyelt ${ }^{17}$ a két szöveg közötti tagadhatatlan kapcsolatra, illetve arra is, hogy a dátumokat figyelembe véve gyakorlatilag lehetetlen, hogy bármelyik szöveg a másikról másolt változat legyen. Mindenképpen meg kell jegyezni azonban, hogy Lengyel cikkében több helyütt is tévesen szerepel a Verhovay név, minden részlet egyértelmüvé teszi ugyanis, hogy Petrovay énekeskönyvére gondol. Azonban nem ez az egyetlen tévedés, amit Lengyelnél találunk. Azt még helyesen állapítja meg, hogy a strófák sorrendje nem azonos a két forrásban, viszont a felsorolása hibásan adja meg a versszakok elhelyezkedését. Nem követ el nagy hibákat, és azokat is valószínüleg véletlenül, de a könnyebb megértés érdekében - követve az általa megadott felosztást - szerintem így írhatjuk fel helyesen a versszakok eltéréseit (a Petrovayénekeskönyv sorrendjét vettem alapul, de azokon a helyeken, ahol a Florentina rendelkezik többlettel, jeleztem a hiányt):

\footnotetext{
14 Régi Magyar Drámai emlékek 2, szerk. Kardos Tibor, Bp., Akadémiai, 1960, 348.

15 STOLL 2002², i. m. 69.

16 Latzkovits Miklós szóbeli közlése.

17 LengYel Dénes, Florentina és Verhovay énekeskönyvének Quaerela puella-je = Irodalomtörténet, 28(1939), 30-31.
} 
Petrovay-énekeskönyv

$1-3$
4
5
6
hiányzik
7
hiányzik
8
9
10
11
12
13
14
15

Florentina

$1-3$
6
hiányzik
9
$10-12$
13
$14-20$
21
hiányzik
4
5
7
8
hiányzik
22

Minden eltérés ellenére láthatunk tehát szorosan összetartozó strófákat, például az 1-3. mindkét forrásban, illetve ahogyan a 10-13. versszakok az énekeskönyvben és (a 6. kivételével) a 4-8. strófák a drámában követik egymást. Ezek a nyilvánvalóan nem a véletlen számlájára írható kapcsolódások közös ősre mutatnak, egy olyan forrásra, amit $\alpha$-val jelölhetünk. Ezt is felvetette már Lengyel Dénes, aki ezek alapján csak feltételezte, amit én szinte bizonyosnak gondolok, vagyis hogy Gyöngyösi nem lehet a versbetét eredeti szerzője; minden valószínűség szerint felhasznált egy esetleg közszájon forgó, mindenesetre már korábban is létező verset. Latzkovits Miklós ellentétes álláspontot képvisel a kérdésben, és a velem szóban megosztott ellenérvei között szerepel, hogy a vers farsangi költemény, mely könnyen, gyorsan, intenzíven terjedhetett kéziratos másolatokban. Ezzel most nem is vitatkoznék, viszont ha így van, annak akkor sem kell feltétlenül azt jelentenie, hogy Gyöngyösitöl eredt a legelső változat - ugyanolyan könnyen juthatott el hozzá is a szöveg, mint ahogy eljutott Petrovayhoz.

Tehát abban az esetben is azon a véleményen vagyok, hogy nem Gyöngyösi a kiindulópont, ha létezett a szövegnek egy korábbi, a drámában olvashatótól különbözö, Gyöngyösi-féle változata, hiszen egyrészt túl nagy az eltérés a két változat között, másrészt, még ha egy szöveg két forrásból való összeillesztéséhez elegendő önállóságot feltételezhetünk is Petrovaytól, azt, hogy külön latin címet adjon egy éneknek, rendkívül valószínütlennek tartom.

Szintén Lengyel mutat rá a hasonlóságra, amely a Petrovay-énekeskönyv 14. strófája (ez a Gyöngyösi-féle változatból hiányzik) és a Szentsei-daloskönyv 53. számú versének 5. strófája ${ }^{18}$ között áll fenn:

18 Szentsei György daloskönyve, sajtó alá rend., előszó és jegyz. Varga Imre, Bp., Helikon, 1977 (Bibliotheca Historica), 268. 
Petrovay-énekeskönyv:

Oh ha már valaki, találkoznék, a' ki

Enghem szíbül szeretne,

Bátor szegény lenne, bár fél szeme lenne,

Bátor ugyan sánta lenne,

Nem gondolnék vélle, czak enghem elvenne,

És szükségemrül tenne

Szentsei-daloskönyv:

De ha engem valaki megkérne,

Annak bátor csak fészeme lenne,

Az lábo is, bátor, bankós lenne,

Csakhogy az én szükségemrül tenne.

A vénlánycsúfolók alapszókészlete és panaszáradata természetesen adott, úgy is mondhatnánk, megvan a kaptafája, e nagymértékű egyezés alapján mégis nagyon valószínủnek látszik, hogy valóban létezett akár a szóbeli, akár a korai írásbeli hagyományban valamilyen változata annak az éneknek, amely aztán megtalálta az útját Petrovayhoz és Gyöngyösihez egyaránt. Azt a lehetöséget, hogy Gyöngyösi eredeti szövege (akár a Florentina-beli, akár egy feltételezhető korábbi változata) került volna be az énekeskönyvbe (ahogy azt $A$ magyar irodalom története feltételezte) ${ }^{19}$, a fenti érvek alapján és meggyőző forrás hiányában rendkívül valószínütlennek tartom.

Végül kitérve a vonatkozó szakirodalomra, megállapítható, hogy abban kevés szó esik Lengyel általam többször idézett cikkéről, az RMDE vonatkozó kötete ${ }^{20}$ is csupán megemlíti, hogy az ominózus közjáték pusztán egyetlen forrásban szerepel, és hogy egy változata megtalálható a „Verhovay-énekeskönyvben”. (Itt mindenképpen meg kell jegyezni, hogy ezzel a sajnálatos tévedéssel, amely Lengyel Dénestől származik, frissnek mondható szakszövegekben is találkozhatunk $)^{21}$ Ebböl is látszik, hogy senki sem vitatkozik Lengyel állításával, jobbára tudomást sem vesznek róla, ami esetleg annak is köszönhető, hogy Gyöngyösi szövegeivel kapcsolatban többször és komolyabb esetekben is felmerültek szerzőségi kérdések. ${ }^{22}$ Minden mellőzöttség ellenére azonban ez is lehet egy adat, amely támogatja, hogy kérdéseket tegyünk fel a Gyöngyösinek tulajdonított szövegek szerzőségével kapcsolatban.

19 A magyar irodalom története 1964, i. m. 315.

20 Régi Magyar Drámai Emlékek 1960, i. m., 351, 352, 354.

21 LaTzKovits Miklós, A drámaírás gyakorlata a 16-17. századi Magyarországon, Bp., Argumentum, 2007, 65.

22 LATZKovits Miklós, MÉszÁros Zoltán, Ki irta a Gyöngyösi Florentináját? = Irodalomtörténeti Közlemények, 109(2005), 469-493; Uö, Gyöngyösi és az imposztorok (Ki irta Gyöngyösi verseit?) = Irodalomtörténeti Közlemények, 123(2019), 263-300. 
Az eddig tárgyalt szöveg után közvetlenül egy Zrínyi halálára írt siratóének olvasható a $102 \mathrm{r}-104 \mathrm{v}$ oldalakon, amely szintén latin címmel szerepel a kéziratban (Cantio Lacrimosa de Excell/entissi/mo Dno Domino quondam Comite Nicolao á Zrinyo. ${ }^{23}$ Nota. Iffiusagom.). Épp a címek nyelvi azonossága miatt egyáltalán nem kizárt, hogy Petrovay ugyanabból a forrásból másolta ezeket az énekeket. A Zrínyivel „kapcsolatba hozható” szöveg a Szentsei-daloskönyvben is megtalálható, ${ }^{24}$ igaz, némiképp eltérő változatban. Bizonyos különbségek azt az elképzelést támogatnák, hogy Petrovay változata közelebb állhatott az eredeti szöveghez, például az alábbi részletek:

Szentsei-daloskönyv

1.

Hol van Virgilius, poéták vezére?

Mert elijede már Horvátország szíve, Föllobbant mint szarvas szép folyóvizekre

9.

Sirast Horvátország jó rendölt uradat

\section{Petrovay-énekeskönyv}

1.

Kelj föl Virgilius, poéták vezére, Mert elégiádra Hovátország színe, Föllobbant mint szarvas szép folyóvizekre

9.

Sirasd Horvát ország jó renddel uradat

Találunk viszont ennek ellentmondó adatokat is, például a 16. strófában, melyben (a Szentsei-daloskönyvvel szemben) kissé értelmetlennek tetsző szöveget olvashatunk Petrovay másolatában:

16.

Sima kengyelérül az Zrényi leugrik, Midőn vadállotra nagy szívvel futamik, Fegyveréhez bízván, jaj, megcsalattatik,

Vége életének mert ottan történik.
16.

Sima tengelyérül szerencse leugrék, Midőn vadállatra nagy szívvel futamék Fegyveréhez bízván, jaj, megcsalattaték, Égő szövétneke ottan eloltaték.

Annak ellenére, hogy az első sor kérdésében a Petrovay-énekeskönyv változatát is tekinthetjük értelmesnek, mégis helyesebbnek tünik a daloskönyvé, különösen annak tükrében, hogy a következő két sor egyértelmüen Zrínyire vonatkozik, és láthatóan nem történik alanyváltás sem. Érdemes még megemlíteni azt a szintén kissé furcsa sort, melyet a 14. strófában találunk:

14.

Fordíttá kerekét Zrényinek sorsához.
14.

Fordítá kerekét Zrínyi gonoszához.

\footnotetext{
23 Siratóének az egykori kiváló úr és gróf Zrínyi Miklósról.

24 Szentsei György daloskönyvei 1977, i. m. 80.
} 
Mivel a szerencséről van szó, a Szentsei-féle változat sokkal inkább tünik igazodni a kontextushoz. A másolási hibák alapján mindenesetre nagyon valószínünek látszik, hogy most sem a nyomtatvány szolgált az énekek forrásául, amit nemcsak a hibák természete, hanem a kronológia is megerősít. Gyöngyösi Florentinája is és a Zrínyiről szóló ének is a másolással közel egy időben keletkeztek (habár a Gyöngyösi által felhasznált szöveg lehetett jóval korábbi is), gyakorlatilag tehát kortárs szövegekről beszélhetünk, melyeknek jelenleg nem tudunk számunkra releváns nyomtatott kiadásáról.

A Petrovay-énekeskönyvben nótajelzés is tartozik a vershez: Ifjúságom. Az Ifjúságom vétke gyakran jut eszemben incipitü bünbocsánati énekről van szó, melyet a kolofon tanúsága szerint 1616-ban szerzett Szepsi Csombor Márton. Érdemes megjegyezni azonban, hogy a vonatkozó RMKT-kötet ${ }^{25}$ jegyzetei alapján a Zrínyiről szóló szöveg első két sora megtalálható Putnoki János emlékkönyvében, amelybe 1617-1622 között kerülhettek bejegyzések Heidelbergben. Ugyanakkor, amint elkezdjük átlapozni az emlékkönyvet, nemcsak ennek az éneknek az első két sorával találkozunk (127), hanem rögtön a második lapon az Ifjúságomnak vétke első két sorával is; az itt található két sor azonban nem egyezik teljesen a Thaly Kálmán által közöltekkel: ${ }^{26}$

„Ifjúságom vétke gyakran jut eszemben, Mely ${ }^{27}$ bánatot indít s siralmat szívemben." /Szepsi Csombor Máté/

„Ifjúságom vétke gyakran jut eszemben,

Kit bínei miatt félek az az"

/Putnoki János emlékkönyvében/

A szakirodalom alapján azt is tudjuk, hogy ez a vers megtalálta az útját az Istenes énekek kiadásaihoz is (amely ponton elvált Szepsi Csombor Márton nevétől), az 1660-as bártfai kiadásban például valóban szerepel (226), viszont ugyanazzal a két sorral kezdődik, amelyekkel az RMKT-ban és Szepsi szövegében is megismerhettük - honnan veszi tehát a második sort a Putnoki-emlékkönyv bejegyzöje? A dolgot az is nehezíti, hogy nem is szabályos bejegyzést olvashatunk, nincs bejegyzési hely, idő megadva, nincs dedikáció, nincs aláírás, ráadásul nem is ez az egyetlen bejegyzés az oldalon, hanem eltérő tintával, más kézírással több inscriptiót is olvashatunk. Közülük csupán a legelsőnek, a lap tetején, van keltezése, amelyet eszerint 1622. július 3-án jegyeztek be az emlékkönyvbe.

Az emlékkönyvi bejegyzésekre jellemző, hogy egy-két szó rosszul szerepel bennük, a fent kimutatott viszont akkora fokú eltérés, amelyet nem írhatunk a

${ }^{25}$ Régi Magyar Költök Tára XVII/8., szerk. Stoll Béla, Bp., Akadémiai, 1976, 535.

26 Régi magyar vitézi énekek és elegyes dalok I-II, kiad. Thaly Kálmán, Pest, Lauffer Vilmos, 1864, II. 15.

${ }^{27}$ Szepsi Csombornál: Ki. 
rosszul müködő emlékezet számlájára (mint ahogy saját fogalmazványnak sem tarthatjuk). Minden bizonnyal ismert szövegből ered tehát; a kérdés csak az, hogy honnan. Mostanáig nem találtam annak nyomát, hogy a szakirodalom ismerné az ének más változatát, így csak reménykedhetünk abban, hogy a jövőben felbukkan valahol.

Ezt a kérdést tehát egyelöre nyitva hagyva és visszatérve a Zrínyiről szóló ének emlékkönyvben megtalálható első két sorára, rendkívül érdekes a 38 strófás ének 35. strófájában olvasható 1664-es szereztetési dátum, hiszen az album jóval korábbi bejegyzéseket tartalmaz. Nem lehet kizárni, hogy maga a tulajdonos, Putnoki János mellékesen jegyzetfüzetnek is használta az albumot, de olyan példákból sincs hiány, hogy évekkel később kerül egy-egy magyar bejegyző kezébe az album, miután a tulajdonosa hazatért a peregrinációból. Szinnyeinél ${ }^{28}$ azt olvassuk Putnoki Jánosról, hogy 1658-ban még élt, pontos halálozási dátumáról viszont nem tudunk. Felmerül azonban a kérdés, vajon az ő tulajdonában volt-e még az emlékkönyv, mikor ezek a (valószínüsíthetően kései) bejegyzések belekerültek. Ha hozzá kötnénk ennek a két sornak az emlékkönyvbe kerülését, felvetődne az a kérdés is, hogy létezett-e egy korábbi, más változata a Zrínyiről szóló éneknek, amelyet esetleg felhasznált és parafrazeált a szerző, hogy 1664-ben a mindenkit megrázó eseményhez, azaz Zrínyi halálához igazítsa. Azért sem elvetendő ez a feltételezés, mert a vers bizonyos strófái felbukkannak a Miszlai András szerezte Siralmas ének az szömörei harcrul címü énekben is. ${ }^{29}$ Vannak természetesen toposzok a régi irodalomban, melyek ismétlödése nem jelent feltétlenül közös forrást (mint pl. a madarak, vadak koporsóhoz való hasonlítása), ebben az esetben azonban talán többről van szó. A következő strófáknál érhető tetten az azonosság:

Siralmas ének...

4.

Apolló hogy hallá ezeknek halálát, Mindjárt ő lantjának mézzel folyó szavát, Mingyárt ủ lantjának mézzel folyó

Citeráját,

Könyveinek árját, Keservesen így kezdé el szavát:

5. Oh, szomorú eset, oh, gonosz szerencse, Oh, szomorú élet, oh, gonosz szerencse,

\section{Petrovay-énekeskönyv}

11.

Apolló hogy hallá ennek ủ halálát, szavát,

Keserves sírással könyvének árját, Citerát pöndítvén így kezdé el szavát.

\section{2.}


9.

Szörnyü! Apollónak zöngedező lantja, Szörnyü! Orpheusnak gyönyörü nótája

Elváltoza, Ékes szép nótája,

Méreggé lőn fülemüle szava.
18.

Szünjön Apollónak zengedező szava, Szünjön Orpheusznak gyönyörü hárfája Fülemülének is zengedező hangja Méreggé változzék hajnali nótája.

Miszlai András nevével kapcsolatban ráadásul nem elöször merül fel, hogy más tollával ékeskedne. A Vígságnak töretik gyönge szép üvege incipitü versével kapcsolatban jegyzi meg Thaly Kálmán, hogy az lehetett az alapja az általa A bujdosó Rákóczi éneke címen közölt versnek. ${ }^{30}$ Varga Imre nyomán azonban tudjuk, hogy ez a vers egy 1695-ben szerzett szöveg strófáiból készült válogatás. ${ }^{31}$ Korábbi tehát, mint a Miszlai nevéhez köthető 1704-es vers. Varga maga is azon az állásponton van, hogy a Lugossy-kódexből származó Sírjatok szemeim ... és a Vígságnak töretik incipitü vers is egy közös forrásra vezethetők vissza, egymástól függetlenül keletkeztek tehát. ${ }^{32}$ Meg is nevezi ezt a forrást, egy a sárospataki iskola sorsát sirató éneket, melynek tanulmányában közli az eddig kiadatlan változatait. ${ }^{33} \mathrm{Ami}$ a közös forrásból való táplálkozást illeti, valószínüleg nincs ez másként a Zrínyiről szóló és a koronczai (szemerei) harcról szóló szöveg esetében sem. Legalábbis elgondolkodtatók az eltérések a változatok között, illetve természetesen a verselés különbözősége is. Elképzelhető azonban az is, hogy jelen esetben Miszlai ismerte a korábbi éneket, és abból emelt át néhány strófát. Péczely László szerint Miszlai és Szentsei együtt bujdoshattak, ${ }^{34}$ Szentsei gyüjteményében pedig nemcsak Miszlai három költeménye található meg, hanem természetesen a Zrínyiről szóló vers is, így (ha hiszünk Péczelynek) nem nehéz elképzelni, hogy tálcán szállította Miszlainak az anyagot, amit ő a korban még nem létező szerzői jog megsértése nélkül kedvére felhasznált. Mindennek tükrében azonban legalábbis érdemes elgondolkodni, mennyi olyan versünk lehet, melyeket egy szerzőnek tulajdonítunk, az ő tehetségét dicsérjük velük, miközben némi utánajárással (és szerencsével) kiderülhet, hogy innen-onnan összetoldozott munkáról beszélhetünk csak.

Visszatérve Petrovayra, az ö kezében talán egy másik énekeskönyv lehetett, de az sem zárható ki, hogy levélben küldte el neki valaki ezeket a verseket. Mivel a gyüjtemény mostani számozása szerint a két érintett ének egymás után következik, és mindkettő rendelkezik latin címmel, meglehet, hogy már Petrovay forrá-

30 THaLy Kálmán, Adalékok a Thököly- és Rákóczi-kor irodalom történetéhez 2, Pest, Ráth Mór, 1872, 412-415.

31 VARGA Imre, Egy bujdosó énekünk történetéhez = Acta historiae litterarum hungaricarum, 13(1973), 123-131, 123.

32 Uo., 126.

33 Uo., 127-129.

34 PÉCZely László, A kuruc költészet egyik remeke (verselemzés) = Jelenkor, 19(1976), 3, 269. 
sában is együtt szerepeltek. Egyáltalán nem könnyíti meg a forrásazonosítást, hogy Petrovay életéről alig rendelkezünk információval. Némi adatot ismerünk róla Petrovay György publikációiból ${ }^{35}$ de ezek is csak felületesen érintik az életét. Annyi bizonyosnak tünik, hogy nem a család Hosszúmezei Bogdán alapította ágához tartozott, mivel akkor szerepelne Zubánics László Vitézi végek dicsérete $e^{36}$ címü könyvében, melyben részletesen ír a családról. Hogy mekkora szerepet játszhatott az irodalmi életben, lehetett-e és milyen mély kapcsolata írókkal, költőkkel, egyelöre nem tudható. Érdemes azonban megjegyezni, hogy a kézirat 132r oldalán a következő jegyzetet találjuk: „In Petrova die 18 Mentis 8tobris 1672 állattam be én Petrovai Miklós szolgálni Szegedi Zsigmond uramhoz kedden." Ez a bejegyzés azért is rendkívül fontos, mert az énekeskönyvben szerepel Szegedi Zsigmond egy költeménye, melyet Bethlen István temetésére írt. ${ }^{37}$ Ezen a ponton pedig gyakorlatilag bizonyítottá válik, hogy Petrovaynak voltak kapcsolatai kortárs költőkkel, így akár kaphatta közvetlenül, levelezés útján is az énekeket, irodalmi kapcsolatainak valódi mélysége azonban egyelöre rejtély; csakúgy, mint a nevéhez köthető énekeskönyv, amelyben müfajok tekintetében kivételesen széles repertoárú kéziratot és rengeteg megválaszolandó kérdést hagyott az utókorra.

35 Petrovay György, A dolhai és a petrovai Petrovayak története 1450-töl napjainkig, Harmadik és befejezö közlemény, 16 czímerrajzzal, Turul, 1897, 170-187.

36 ZuBánics László, Vitézi végek dicsérete, A nemesség szerepe a XVI-XVII. századi Északkelet-Magyarország társadalmi fejlődésében, Ungvár, Intermix Kiadó, 2016.

${ }^{37}$ Régi magyar költök tára, XVII. század, 9, A két Rákóczi György korának költészete 1630-1660, kiad. Varga Imre, Bp., Akadémiai, 1977, 262-263. 


\section{Schelhammer, Zsófia}

\section{The appearance of Miklós Zrínyi and István Gyöngyösi in a 17th century songbook}

At the centre of my study are two texts from the Petrovay songbook. It is a manuscript that, although long known to literary history, still plays a somewhat neglected role in the technical literature. The collection was compiled between 1668 and 1677 by Miklós Petrovay, a nobleman from Maramureș; we can encounter mainly lays in it, but we can also read many prose writings and contemporary poems too.

In this paper, I deal with two works in the latter category, more specifically with the appearance of Miklós Zrínyi and István Gyöngyösi, mostly with the intention of proving that Gyöngyösi was not the genuine writer of Electra's monologue in scene 5 of Florentina's 3rd act. In my opinion he merely used up an already existing spinster mockery, that (or whose common ancestor) can be read in the Petrovay songbook. The literature practically treats it as a fact that the song comes from Gyöngyösi's Florentina, and there is really no doubt about the connection between the two versions, but there is the problem of the chicken and the egg. The two versions were so close in time that I consider it extremely unlikely that Gyöngyösi's own poem would have found its way to Miklós Petrovay in such a short time. Especially in light of the fact that one of the stanza of the poem, though in a slightly different form, is to be found in a third source, a spinster mockery in the Szentsei songbook.

Keywords: 17 th century, poems, literatur, Petrovay songbook, István Gyöngyösi. 